Article

\title{
Effects of Global Oil Price on Exchange Rate, Trade Balance, and Reserves in Nigeria: A Frequency Domain Causality Approach
}

\section{O. Olayungbo}

Economics Department, Obafemi Awolowo University, Ile-Ife 220282, Nigeria; doolayungbo@oauife.edu.ng

Received: 2 January 2019; Accepted: 25 February 2019; Published: 13 March 2019

\begin{abstract}
This study investigated the relative Granger causal effects of oil price on exchange rate, trade balance, and foreign reserve in Nigeria. We used seasonally adjusted quarterly data from 1986Q4 to 2018Q1 to remove predictable changes in the series. Given the non-stationarity of our variables, we found cointegration to exist only between oil price and foreign reserve. The presence of cointegration implied the existence of long run relationship between the variables. The Granger causality result showed that oil price strongly Granger caused foreign reserve in the short period. However, no Granger causal relationships were found between oil price and trade balance and for oil price and exchange rate. The implication of the result is that Nigerian government should not rely solely on oil price to sustain her reserve but to diversify the economy towards non-resource production and export for foreign exchange generation.
\end{abstract}

Keywords: oil price; exchange rate; trade balance; cointegration; frequency domain causality; Nigeria

\section{Introduction}

Crude oil has been the largest component of the volume of export in Nigeria ever since in the 1970s when the non-renewable commodity was found in commercial quantities. Crude oil accounts for almost 83.5 percent of the total export in the country (Centre for Study of Economies of Africa 2018). Crude oil has been the major driver of the Nigerian economy and any changes in its price usually have significant effects not only on the structure but also the growth and welfare of the citizens. In spite of the abundance of oil in the country, Nigeria has become net importer of refined oil due to the underutilization of her existing refineries. The situation in the country is exportation of crude oil and importation of refined petroleum product at higher cost. This cost implication has a significant impact on the trade balance and the macroeconomic performance of the country.

As an oil dependent economy, Nigeria remains susceptible to the movements in global crude oil prices. During the periods of high oil price resulted from the macroeconomic and political conditions in the international market, the country usually experiences favorable trade balance, increase in foreign reserves, and exchange rate appreciation. On the contrary, when crude oil prices are low, occasioned by happenings in the international markets, the consequences are exchange rate depreciation, significant drop in the level of foreign exchange inflows, and reserve depletion that often result in budget deficit and slower growth. The drastic fall in the global oil price in 2008 and 2015 from over US\$100 to below US $\$ 40$ are great instances that led to the depreciation in exchange rate and deficit in the trade balance of the country. Similarly, the depreciation of the exchange rate from N231 per US\$1 to N305 in the third quarter of 2016 has been associated with the fall in the global oil price, specifically below US $\$ 50$.

As a result of the significance of the effects of oil prices on macroeconomic variables, many previous studies have attempted to examine the relationship among oil price, exchange rate, and trade balance. Some of these studies include Ozlale and Pekkurnaz (2010); Hassan and Zaman (2012); and 
Tiwari and Olayeni (2013). According Ozlale and Pekkurnaz (2010), oil price significantly affected trade balance. On the other hand, in the area of the effects of oil price on exchange rate, while Hassan and Zaman (2012) and Tiwari and Olayeni (2013) concluded that there are negative relationships between oil price and exchange rate for India. Studies such as Olomola and Adejumo (2006) and Aliyu (2009) found a positive relationship between oil price and exchange rate for Nigeria. Several other studies—such as Rautava (2004); Yousefi and Wirjanto (2004); Nikbakht (2010); Al-Ezzee (2011); and Benhabib et al. (2014)—have also examined causal relationships between oil price and exchange rate. Other studies_Rautava (2004); Yousefi and Wirjanto (2004); Nikbakht (2010); Al-Ezzee (2011)—found a significant relationship between oil price and exchange rate while Benhabib et al. (2014) found a negative relationship. In other words, apart from the inconclusiveness of the literature on the causal effects of oil price on exchange rate and trade balance, previous studies have employed causal analysis in the time domain which cannot analyze causality in the short-, medium-, and long-term but only at a point in time. Furthermore, the frequency domain analysis, on the other hand, provides the frequency and timing where causality exists. This identified shortcoming in this area motivates the use of frequency domain analysis. Studies that have applied the frequency domain causality in the literature are Breitung and Candelon (2006) for the United States (US); Croux and Reusens (2013) for G-7 countries; Yanfeng (2013) for the Japanese economy; Tiwari et al. (2015) for nine EU countries; Dergiades et al. (2015) for seven selected European Union (EU) countries; Bayat et al. (2015) for Czech Republic, Poland, and Hungary; Ozer and Kamisli (2016) for Turkey; Tiwari and Kyophilavong (2017) for India; and Bouri et al. (2017b) for China and India. A more recent study was done by Huang et al. (2018) for the US and nine EU countries. The frequency domain analysis has been known to provide time varying outcomes in terms of low and high frequency in the modeling of the relationship between financial and energy variables than the time domain approach. The frequency analysis is important for both the policy and decision makers in the energy sector as it enables them to know and plan ahead of time unlike in the time domain where causality is just assumed to exist without the knowledge of the period of timing and its frequency. Therefore, the decomposition of the frequency domain causality into different timings and frequencies gives a more in-depth understanding of economic phenomena than the time domain analysis. The objective of this study is to examine the dynamic effects of oil price on some selected macroeconomic variables in Nigeria. Our results show that short term causality exists from oil price to foreign reserve while causality is not found from oil price to trade balance and exchange rate, respectively. The rest of the paper is as follows. Section 2 gives the summary of the existing literature in tabular form, Section 3 has the descriptive statistics, the unit root tests, and the cointegration test. Section 4 describes the frequency domain causality, Section 5 provides the discussion of results, while Section 6 concludes and provides policy recommendations.

\section{Literature Review}

Tables 1-3 summarize the literature on the relationship between oil price, trade balance, and exchange rate in tabular form as follows: 
Table 1. Summary of empirical Evidence on trade balance and exchange rate.

\begin{tabular}{|c|c|c|c|c|}
\hline Author(s) & Country/Countries & Sample Period & Methodology & Results/Conclusion of the Study \\
\hline $\begin{array}{l}\text { Danmola and Olateju } \\
\text { (2013) }\end{array}$ & Nigeria & 1980 to 2010 & OLS & $\begin{array}{l}\text { Exchange rate volatility has a positive } \\
\text { influence on GDP, FDI, and trade. }\end{array}$ \\
\hline $\begin{array}{l}\text { Shehu and Youtang } \\
\text { (2012) }\end{array}$ & $\begin{array}{l}\text { Sub-Sahara African } \\
\text { countries with exclusive } \\
\text { reference to Nigeria }\end{array}$ & 1970 to 2009 & $\begin{array}{l}\text { Augmented Dickey } \\
\text { Fuller (ADF), Granger } \\
\text { causality test }\end{array}$ & $\begin{array}{l}\text { The study concluded that the } \\
\text { exchange rate has significant impact } \\
\text { in influencing exports, imports, and } \\
\text { economic growth. }\end{array}$ \\
\hline Udoh et al. (2012) & Nigeria & 1968 to 2010 & $\begin{array}{l}\text { Cointegration test, } \\
\text { ECM }\end{array}$ & $\begin{array}{l}\text { The study showed that exchange rate } \\
\text { volatility reduces with external } \\
\text { reserves, lending interest rate, and } \\
\text { import. }\end{array}$ \\
\hline Zheng (2012) & Thailand and China & 1997 to 2011 & GLS & $\begin{array}{l}\text { The results indicated that the } \\
\text { exchange rate volatility has a positive } \\
\text { impact on the Thailand export to } \\
\text { China and the exchange rate has no } \\
\text { significant impact on GDP. }\end{array}$ \\
\hline Joseph and Isaac (2011) & Nigeria & 1970 to 2009 & GARCH & $\begin{array}{l}\text { The study showed indirect and } \\
\text { insignificant relations between trade } \\
\text { and exchange rate. }\end{array}$ \\
\hline Ogbonna (2011) & Nigeria & 1970 to 2005 & OLS & $\begin{array}{l}\text { The study revealed that there is no } \\
\text { cointegration for trade balance model. }\end{array}$ \\
\hline $\begin{array}{l}\text { Oladipupo and } \\
\text { Onotaniyohuwo (2011) }\end{array}$ & Nigeria & 1970 to 2008 & OLS & $\begin{array}{l}\text { The study claimed that exchange rate } \\
\text { has significant effects on balance of } \\
\text { payments. }\end{array}$ \\
\hline Olayungbo et al. (2011) & $\begin{array}{l}\text { Sub-Sahara African } \\
\text { countries }\end{array}$ & 1986 to 2005 & $\begin{array}{l}\text { OLS and panel } \\
\text { generalised method of } \\
\text { moment }\end{array}$ & $\begin{array}{l}\text { The result showed that exchange rate } \\
\text { has positive effect on aggregate trade. }\end{array}$ \\
\hline Ng et al. (2008) & Malaysia & 1955 to 2006 & VECM & $\begin{array}{l}\text { The results concluded the existence of } \\
\text { long run effects between trade } \\
\text { balance and exchange rate. }\end{array}$ \\
\hline Baak (2004) & East Asian countries & 1981 to 2004 & $\mathrm{ECM}$ & $\begin{array}{l}\text { The study showed that exchange rate } \\
\text { volatility had a significant short and } \\
\text { long run effects on exports. }\end{array}$ \\
\hline Rose (1990) & $\begin{array}{l}\text { Organization for Economic } \\
\text { Cooperation and } \\
\text { Development countries } \\
\text { (OECD) }\end{array}$ & \multicolumn{2}{|c|}{ Parametric and Non-parametric } & $\begin{array}{l}\text { The study concluded that exchange } \\
\text { rate has insignificant impact on trade } \\
\text { balance. }\end{array}$ \\
\hline
\end{tabular}

Notes: OLS-ordinary least square, ECM-error correction modeling, GLS-generalized least square,

GARCH-generalized autoregressive conditional heteroscedasticity, VECM-vector error correction model.

Table 2. Empirical evidence on oil price and trade balance.

\begin{tabular}{|c|c|c|c|c|}
\hline Author(s) & Country/Countries & Sample Period & Methodology & Results/Conclusion of the Study \\
\hline $\begin{array}{l}\text { Tiwari and Olayeni } \\
\text { (2013) }\end{array}$ & India & 1980 to 2011 & Wavelet analysis & $\begin{array}{l}\text { The study showed that oil price has } \\
\text { negative effect on trade balance }\end{array}$ \\
\hline $\begin{array}{l}\text { Hassan and Zaman } \\
\text { (2012) }\end{array}$ & Pakistan & 1975 to 2010 & ARDL & $\begin{array}{l}\text { The result showed that there is a } \\
\text { significant negative effect of oil price on } \\
\text { both exchange rate and trade balance. }\end{array}$ \\
\hline Qiangian (2011) & China & 1999 to 2008 & VECM & $\begin{array}{l}\text { The study revealed that there exists a } \\
\text { long-term equilibrium relationship } \\
\text { among oil price and output, inflation, } \\
\text { trade balance, and money supply. }\end{array}$ \\
\hline $\begin{array}{l}\text { Ozlale and } \\
\text { Pekkurnaz (2010) }\end{array}$ & Turkey & 1999 to 2009 & VAR & $\begin{array}{l}\text { The study affirmed that oil price has } \\
\text { significant effects on trade balance in the } \\
\text { short run. }\end{array}$ \\
\hline
\end{tabular}

Notes: ARDL—autoregressive distributed lag, VECM—vector error correction model, VAR—vector autoregression. 
Table 3. Empirical evidence on oil price and exchange rate.

\begin{tabular}{|c|c|c|c|c|}
\hline Author(s) & Country/Countries & Sample Period & Methodology & Results/Conclusion of the Study \\
\hline Shafi et al. (2013) & France & 1971 to 2012 & ECM & $\begin{array}{l}\text { The study concluded that the impact of } \\
\text { oil price on exchange rate is positive in } \\
\text { the long run. }\end{array}$ \\
\hline $\begin{array}{l}\text { Benhabib et al. } \\
\text { (2014) }\end{array}$ & Algeria & 2003 to 2013 & VAR & $\begin{array}{l}\text { The study indicated that oil price has } \\
\text { impacted Algerian currency. }\end{array}$ \\
\hline Al-Ezzee (2011) & Bahrain & 1980 to 2005 & VECM & $\begin{array}{l}\text { The study affirmed the existence of a long } \\
\text { run relationship between real GDP } \\
\text { growth, global oil price, and exchange } \\
\text { rate. }\end{array}$ \\
\hline Nikbakht (2010) & OPEC members & 2000 to 2007 & Panel cointegration test & $\begin{array}{l}\text { The result showed that oil price may have } \\
\text { a dominant share of real exchange rate } \\
\text { movement. }\end{array}$ \\
\hline Aliyu (2009) & Nigeria & 1986 to 2007 & VAR & $\begin{array}{l}\text { The study suggested the diversification of } \\
\text { both the infrastructure and the economy. }\end{array}$ \\
\hline $\begin{array}{l}\text { Chen and Chen } \\
(2007)\end{array}$ & G7 countries & 1992 to 2005 & Panel co-integration & $\begin{array}{l}\text { The study found that there is a link } \\
\text { between oil price and exchange rate. }\end{array}$ \\
\hline $\begin{array}{l}\text { Gounder and } \\
\text { Bartleet (2007) }\end{array}$ & New Zealand & 1989 to 2006 & VAR & $\begin{array}{l}\text { Oil price has substantial effect on inflation } \\
\text { and exchange rate in New Zealand. }\end{array}$ \\
\hline $\begin{array}{l}\text { Habib and } \\
\text { Kalamova (2007) }\end{array}$ & $\begin{array}{l}\text { Russia, Norway, } \\
\text { and Saudi -Arabia }\end{array}$ & 1980 to 2006 & VAR & $\begin{array}{l}\text { There is no significant evidence to } \\
\text { maintain that the diverse exchange rate } \\
\text { regimes of the countries may account for } \\
\text { the different empirical results on the } \\
\text { impact of oil price. }\end{array}$ \\
\hline $\begin{array}{l}\text { Yousefi and } \\
\text { Wirjanto (2004) }\end{array}$ & OPEC Countries & 1970 to 1999 & $\begin{array}{l}\text { Novel empirical } \\
\text { approach }\end{array}$ & $\begin{array}{l}\text { The study revealed that regional price } \\
\text { correlations appeared to be indicative of } \\
\text { segmentation within the OPEC market } \\
\text { structure. }\end{array}$ \\
\hline
\end{tabular}

Notes: VECM-vector error correction model, VAR-vector autoregression.

In summary, from the empirical literature, the results from the review show different evidence regarding the issue of trade balance, oil price, reserve, and exchange rate. Firstly, it can be observed that extensive studies have been done on trade balance and exchange rate, oil price and exchange rate in both developed and less developed countries. Most of the literature highlighted made use of time domain analysis and studies that have applied frequency domain analysis were mainly on developed countries with few on developing countries. This study, therefore, contributes to the existing literature by applying the frequency domain causality on oil price and macroeconomic variables in Nigeria.

\section{Data Analysis}

This section presents the definition of variables used, their data sources, descriptive statistics of variables used, the unit root tests and the cointegration test employed in this study.

\subsection{Variable Definition and Data Sources}

The data used for this study is from the period of 1986Q4 to 2018Q1. The choice of a single country study and period are informed by data availability. Apart from these limitations, the sample country is the largest exporter of oil in Africa and her economy is largely driven by oil price. The variables used are oil price, trade balance, exchange rate, and trade balance. Trade balance is the volume of aggregate 
export of goods and services minus aggregate import of goods and services measured in naira. Oil price, on the other hand, is the price at which Brent crude oil is sold per barrel at each quarter measured in US dollar in the international oil market. The exchange rate is the relative price of exchange of the units of naira to the units of dollar. Lastly, foreign reserve is measured as the financial assets held in the form of US dollars in the country's treasury. The trade balance, reserve, and exchange rate were sourced from the Central Bank of Nigeria Statistical Bulletin (2018) while the oil prices sourced from the Energy Information Administration, US Federal Statistical System (2018). It should be noted that the data employed have been adjusted from their sources of any predictable changes that can overstate their true values.

\subsection{Descriptive Analysis}

The description of the data used in this study as presented in Table 4 shows the average value of $\$ 43.58$ for oil price; $\$ 97.79$ for exchange rate; $\$ 19,163$ billion for reserve; and $\$ 168,856$ billion for trade balance for the period of study. The exchange rate measured in US dollars has fluctuated widely

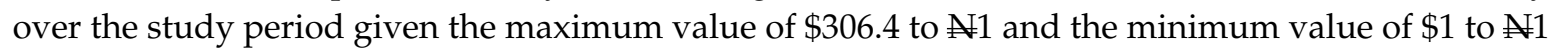
during the study period. The volatility change is also true of the oil price with a maximum value of $\$ 123.78$ and minimum value of $\$ 12.93$ over the study period. The movement is correlated with both reserve and trade balance with maximum values of $\$ 60,875$ billion and $\$ 718,742$ billion respectively and minimum value of $\$ 913$ million and $\$ 142$ million respectively. The relationship in the movement of the variables shows the response of the selected macroeconomic variables to oil price over the study period.

Table 4. Descriptive statistics.

\begin{tabular}{ccccc}
\hline Statistics & Exchange Rate & Oil Price & Reserve & Trade Balance \\
\hline Mean & 97.79 & 43.58 & 19,163 & 168,856 \\
Median & 116.04 & 28.92 & 9101.47 & $79,865.46$ \\
Maximum & 306.4 & 123.78 & $60,875.24$ & 718,742 \\
Minimum & 1 & 12.93 & 913 & 141.59 \\
Std-dev & 80.96 & 29.62 & $17,121.85$ & 198,198 \\
Jacque-Bera & 9.38 & 18.33 & 14.53 & 25.11 \\
Prob. & 0.00 & 0.00 & 0.00 & 0.00 \\
observation & 129 & 129 & 129 & 129 \\
\hline
\end{tabular}

\subsection{Unit Root Tests}

The unit root tests of augmented Dickey-Fuller (ADF, Dickey and Fuller 1981) and the Phillips-Perron (PP, Phillips and Perron 1988) are carried out to ensure the stationarity of the variable of interest. From Table 5, it can be observed that all the variables are stationary at first difference with both ADF and PP except trade balance which is stationary at first difference with ADF but not with PP. The stationarity of the variables is important for the application of the frequency domain causality.

Table 5. Augmented Dickey-Fuller and Phillip-Perron.

\begin{tabular}{cccccc}
\hline Variables & Levels & First Diff. & Variables & Level & First Diff. \\
\hline Exchange rate & 0.637 & $-8.9128^{* * *}$ & Exchange rate & 1.0743 & $-8.8182^{* * *}$ \\
Oil price & -1.5666 & $-9.5175^{* * *}$ & Oil price & -1.4847 & $-8.9468^{* * *}$ \\
Reserve & -1.0742 & $-4.0827^{* * *}$ & Reserve & -0.9562 & $-8.0429^{* * *}$ \\
Trade Balance & -2.6008 & -15.4233 & Trade Balance & -3.5938 & - \\
\hline
\end{tabular}

The critical values are $-3.4824,-2.8843$, and -2.5790 at $1 \%, 5 \%$, and $10 \%$ respectively. ${ }^{* * *}$ signifies $1 \%$ significance level. 


\subsection{Cointegration Tests}

The next step is to verify if cointegration exists between the non-stationary variables of interest using the Johansen (1988) multivariate cointegration test. We conducted a bivariate cointegration test separately between oil price and each of the other three variables in order to ensure consistency with the bivariate frequency domain causality approach. This cointegration test compares the Eigenvalue and the trace statistics with their critical values to determine the presence of cointegration. The null hypothesis is the rejection of cointegration if the Eigen or trace statistics is greater than the critical value. From Table 6, the cointegration between oil price and reserve, $r=0$ is rejected at 5 percent significance level with the value of 14.76 of the Eigen statistics greater than the critical value of 14.26 . However, the null hypothesis of no cointegration cannot be rejected for $r \leq 1$ because the Eigen statistics value of 0.68 is less than the critical value of 3.84. The same for the trace statistics. We therefore conclude that there is at least one cointegrating relationship between oil price and foreign reserve. However, the test of cointegration between oil price and trade balance, $r=0$ is rejected for both the Eigen and the trace statistics, because their values of 11.6 and 13.43 are less than there critical values of 14.26 and 15.49. The same is true for the cointegrating relationship between oil price and exchange rate. We therefore conclude that there is no long run relationship between oil price and trade balance on one hand and no long run relationship exists between oil price and exchange rate on another. Long run cointegration exists only between oil price and foreign exchange reserves. In other words, the study found the bivariate cointegration system to exist only for oil price and reserve in the study period.

Table 6. Johansen unrestricted bivariate cointegration results.

\begin{tabular}{|c|c|c|c|c|c|c|}
\hline Coint. Rank & Eigen Value & Critical Value & Prob. & Trace Stat. & Critical Value & Prob. \\
\hline \multicolumn{7}{|c|}{ Oil price and reserve } \\
\hline$r=0$ & 14.76 & 14.26 & $0.04 * *$ & 15.45 & 15.49 & 0.05 * \\
\hline$r \leq 1$ & 0.68 & 3.84 & 0.41 & 0.68 & 3.84 & 0.41 \\
\hline \multicolumn{7}{|c|}{ Oil price and trade balance } \\
\hline$r=0$ & 11.6 & 14.26 & 0.13 & 13.43 & 15.49 & 0.10 \\
\hline$r \leq 1$ & 1.82 & 3.84 & 0.18 & 1.82 & 3.84 & 0.18 \\
\hline \multicolumn{7}{|c|}{ Oil price and exchange rate } \\
\hline$r=0$ & 11.49 & 15.49 & 0.18 & 10.61 & 14.26 & 0.17 \\
\hline$r \leq 1$ & 0.88 & 3.84 & 0.35 & 0.87 & 3.84 & 0.35 \\
\hline
\end{tabular}

\section{Methodology}

In this study, we propose the granger causality in the frequency domain following Croux and Reusens (2013) as opposed to the usual time domain causality test. Many previous studies have applied frequency domain causality to wide areas of economic research. In earlier years, Breitung and Candelon (2006) investigated the predictive content of the yield spread for future output growth using United State (US) quarterly data. Also, Yanfeng (2013) applied the frequency domain causality on the dynamic effects of oil prices on the Japanese economy. In recent years, Dergiades et al. (2015) examined the effects of social media (Twitter, Facebook, and Google blogs) and web search intensity (Google) on financial markets with the use of frequency domain causality for Greece, Ireland, Italy, Portugal, and Spain and separately for two Euro countries, France, and The Netherlands. In addition, Bayat et al. (2015) investigated causal relationship between oil price and exchange rates in Czech Republic, Poland, and Hungary by employing frequency domain causal approach. In the same manner, Ozer and Kamisli (2016) used the frequency domain causality analysis to study the interactions between financial markets in Turkey. Likewise, Tiwari and Kyophilavong (2017) studied the relationship between exchange rate and international reserves for India using a frequency 
domain analysis. Bouri et al. (2017b) also adopted frequency domain causality to investigate the short-, medium-, and long-run causal relations among crude oil, wheat, and corn markets in the US. In another paper, Bouri et al. (2017a) used implied volatility indices with frequency domain analysis to examine the short and long-term causality dynamics between gold and stock market in China and India. In a more recent paper, Huang et al. (2018) investigated oil price effect on tourist arrivals to explain oil price effects on tourism-related economic activities for US and nine EU countries using frequency analyses. The modeling of the bivariate frequency domain starts from the time domain model as

$$
\begin{aligned}
& \Delta X_{t}=\alpha_{0}+\sum_{i=1}^{n} \alpha_{i} \Delta X_{t-i}+\sum_{i=1}^{n} \lambda_{i} \Delta Y_{t-i}+\varepsilon_{1 t} \\
& \Delta Y_{t}=\beta_{0}+\sum_{i=1}^{n} \beta_{i} \Delta X_{t-i}+\sum_{i=1}^{n} \omega_{i} \Delta Y_{t-i}+\varepsilon_{2 t}
\end{aligned}
$$

The vector autoregression (VAR) in the time domain is then modified to frequency domain by Geweke (1982) to a bivariate and two-dimensional causal form of two stationary variables $X_{t}$ and $Y_{t}$ as

$$
\Theta(L)\left(\begin{array}{c}
X_{t} \\
Y_{t}
\end{array}\right)=\left(\begin{array}{cc}
\Theta_{11}(L) & \Theta_{12}(L) \\
\Theta_{21}(L) & \Theta_{22}(L)
\end{array}\right)\left(\begin{array}{c}
X_{t} \\
Y_{t}
\end{array}\right)=\left(\begin{array}{c}
\varepsilon_{1 t} \\
\varepsilon_{2 t}
\end{array}\right)
$$

where $\Theta(L)=1-\Theta_{1} L-\Theta_{2} L^{2}-\cdots-\Theta_{\rho} L^{\rho}$ is a $2 \times 2$ lag polynomial of order $\rho$ with $L^{j} X_{t}=X_{t-j}$ and $L^{J} Y_{t}=Y_{t-j}$. The vector of error, $\varepsilon_{t}=\left(\varepsilon_{1 t}, \varepsilon_{2 t}\right)^{\prime}$ is assumed to be stationary with $E\left(\varepsilon_{t}\right)=0$ and $E\left(\varepsilon_{1 t}, \varepsilon_{2 t}\right)^{\prime}=\Sigma$, where $\Sigma$ is positive definite and symmetric. Applying the Cholesky decomposition, $G / G=\Sigma^{-1}$, where $G$ is a lower triangular matrix and $G^{\prime}$ is an upper triangular matrix, the $M A$ representation of the model is expressed as

$$
\left(\begin{array}{c}
X_{t} \\
Y_{t}
\end{array}\right)=\Phi(L)\left(\begin{array}{c}
\eta_{1 t} \\
\eta_{2 t}
\end{array}\right)=\left(\begin{array}{ll}
\Phi_{11}(L) & \Phi_{12}(L) \\
\Phi_{21}(L) & \Phi_{22}(L)
\end{array}\right)\left(\begin{array}{c}
\eta_{1 t} \\
\eta_{2 t}
\end{array}\right)
$$

where $\Phi(L)=\Theta(L)^{-1} G^{-1}$ and $\left(\eta_{1 t}, \eta_{2 t}\right)^{\prime}=G\left(\varepsilon_{1 t}, \varepsilon_{2 t}\right)^{\prime}$, so that $\operatorname{cov}\left(\eta_{1 t}, \eta_{2 t}\right)=0$ and $\operatorname{var}\left(\eta_{1 t}\right)=$ $\operatorname{var}\left(\eta_{2 t}\right)=1$. Equation (3) means that $X_{t}$ is a sum of two uncorrelated $M A$ processes. Specifically, it is the sum of an intrinsic component driven by past shocks in $X_{t}$ and a component containing the causal component of the variable $Y_{t}$. The causal component of $Y_{t}$ at each frequency $\omega$ can be derived by comparing the causal component of the spectrum with the intrinsic component at the frequency. $Y_{t}$ does not granger cause $X_{t}$ at frequency $\omega$ if the causal component of the spectrum of $X_{t}$ at frequency $\omega$ is zero. According to Geweke (1982), the measure of causality is defined as

$$
M_{y \rightarrow x}(\omega)=\log \left[1+\frac{\left|\Phi_{12}\left(e^{-i \omega}\right)\right|^{2}}{\left|\Phi_{11}\left(e^{-i \omega}\right)\right|^{2}}\right]
$$

This measure of causality is the ratio of the total spectrum divided by the intrinsic component of the spectrum. It is expressed as $M_{y \rightarrow x}(\omega)=0$ if $\left|\Phi_{12}\left(e^{-i \omega}\right)\right|=0$. Hence, the term $\left|\Phi_{12}\left(e^{-i \omega}\right)\right|=0$ provides a condition of no granger causality at frequency $\omega$. For simplicity, Breitung and Candelon (2006), show that condition of no granger causality at frequency $\omega$ can be represented in a set of linear restrictions on the coefficient of the components of the VAR model in Equation (2) as

$$
X_{t}=\sum_{i=1}^{\rho} \Theta_{11 i} X_{t-i}+\sum_{i=1}^{\rho} \Theta_{12 i} Y_{t-i}+\varepsilon_{1 t}
$$


where $\Theta_{11 i}$ and $\Theta_{12 i}$ are the coefficients of the lag polynomials $\Theta_{11}(L)$ and $\Theta_{12}(L)$. The necessary and sufficient conditions for absence of granger causality at frequency $\omega$ can be written as

$$
\left\{\begin{array}{l}
\sum_{i=1}^{\rho} \Theta_{12 i} \cos (i \omega)=0 \\
\sum_{i=1}^{\rho} \Theta_{12 i} \sin (i \omega)=0
\end{array}\right.
$$

The linear restriction in Equation (6) on the coefficients can be tested by a standard $F$-test. The $F$-statistics is distributed as $F(2, T-2 \rho)$. Where 2 is the number of restrictions and $T$ is the number of observations used to estimate the VAR model of order $\rho$. In the same vein, the linear restrictions in Equation (6) can be tested by an incremental $R$-squared test, measuring the proportion of explained variability of $X_{t}$ lost as a result of the imposition of the two restrictions in Equation (6). The incremental $R$-squared is the difference between the $R$-squared test $R^{2}$ of the unrestricted equation in Equation (5) and the $R$-squared test $R^{2}$ of the equation estimated in Equation (6). The incremental $R$-squared can be explicitly written as

$$
\text { Incremental } R^{2}=R^{2}-R_{*}^{2}
$$

The incremental $R$-squared test is the strength of the granger causality from $Y_{t}$ to $X_{t}$ at frequency $\omega$ and it lies between 0 and 0.01 according to Equation (5). The plot of the incremental $R$-squared of the frequencies is between 0 and $\pi$. It describes the strength of the Granger causality in the frequency domain $(0, \pi)$. The null hypothesis of absence of Granger causality at the frequency $\omega$ is rejected at significance level $\alpha$ on the condition that

$$
\text { Incremental } R^{2}>F_{(2, T-2 P, 1-\alpha)} \frac{2}{T-2 \rho}\left(1-R^{2}\right)
$$

where $F_{(2, T-2 \rho, 1-\alpha)}$ is the $\alpha$ upper critical value of the $F$-distribution with 2 and $T-2 \rho$ degree of freedom (Croux and Reusens 2013). As regards the lag length, which is crucial to the causality test, the Schwarz information criterion (SIC) is chosen among the other criterion with the true lag length order of 3 is chosen for the causality between oil price and reserve, lag 2 for oil price and trade balance, and lag 1 for causality between oil price and exchange rate (Asghar and Abid 2007). The results of the lag length selection criteria are presented at the Appendix A.

\section{Discussion of Results}

The frequency domain causality is carried out after ensuring the stationarity of the variables to investigate the causal effects of oil price on reserve, trade balance, and exchange rate in Nigeria. The short term causality is assumed to be periodicities (frequency) less than 1.5, while the periodicity of 1.5 is the intermediate term and the long term causality is the frequency greater than 1.5. In this study, Equation (5) is estimated separately with oil price as exogenous variable to reserve, trade balance, and exchange rate. This is so modeled because oil price is exogenous to Nigeria's economy. The global oil prices are dictated by the economic conditions in the international market which are external to the sample country's economy. As a result, we perform separate Granger causality tests for $Y_{t}$ on $X_{t}$. In the model; $Y_{t}$ stands for oil price; while $X_{t}$ represents reserve, trade balance, and exchange rate. The results of the granger causality tests are presented in Figure 1 . The first figure shows that oil price granger causes reserve in Nigeria at 0.001 incremental $R$-squared, that is, $0.001 \%$ critical value with a frequency of value of 1.0. The 0.001 incremental $R$-squared can be interpreted to mean that there is $99.999 \%$ confidence level of causality between oil price and reserve in Nigeria. This means that oil price strongly determines the level of reserve in Nigeria in the short term with the 1.0 frequency value. The periodicity is calculated by $S=\pi /(2 \omega)$, where $S$ is the year of periodicity, $\pi$ is 3.1416 and $\omega$ is 1.0 in this case. From the calculation, the periodicity is 18 months, equivalent to 1 year and 6 months. This implies that oil price usually has significant impact on reserves at every 1 year and 6 months and that 
the occurrence of causality is at every short period. The previous presence of cointegration between oil price and foreign reserve confirms the existence of frequency Granger causality between the two variables. Our result of short-term frequency causality from oil to reserve is in line with a previous study done by Yanfeng (2013) for Japanese, where oil prices was found to have causal effects on the Japanese economy at short term frequency. Our findings of short term causal relationship between oil price and reserve is consistent with Nigeria's experience. Higher oil price has always been associated with higher reserve while low oil price is linked to low reserve. For example, in 2008, oil price was around US\$103 and Nigeria's reserve hit about US\$60 billion. In the same vein, reserve fell to US\$23 billion with a fall in oil price to US\$37 in 2015. On the other hand, causality is not found from oil price to trade balance. The absence of cointegration between oil price and trade balance corroborates the result for the frequency granger causality test. The outcome of the causality may be as a result of recent increase in non-oil export, such as solid minerals, agricultural products, and manufactured exports. The recent exported agricultural products are cashew nuts, sesame, shrimps, soya beans, ginger, cocoa. Although oil still dominates exports in Nigeria, yet government is making concerted effort towards diversifying the economy away from oil as laid down in the Nigerian Economic Recovery and Growth Plan (NERGP) on zero oil agenda. The result of no causal relationship from oil price to trade balance supports a previous study carried out on US and nine EU countries by Huang et al. (2018) that also found no causal effects from oil price to tourism-related economic activities. Lastly, causality is also not found from oil price to exchange rate. The cointegration result is also in line with the granger causality result. The frequent use of foreign exchange to stabilize the exchange rate level by the central bank of Nigeria (CBN) periodically may explain the absence of causal effects of oil price on the exchange rate. Nigeria practices a managed floated exchange rate system. Such exchange rate policy intervention can greatly eliminate the effects of oil price on the exchange rate. Our findings supported a previous study conducted by Habib and Kalamova (2007) for Russia, Norway, and Saudi Arabia that no significant causal relationship exists between oil price and exchange rate for the oil rich countries. It is also in support of a more recent paper by Bayat et al. (2015) that oil price does not have causal effect on exchange rate in Hungary with frequency domain analysis. 


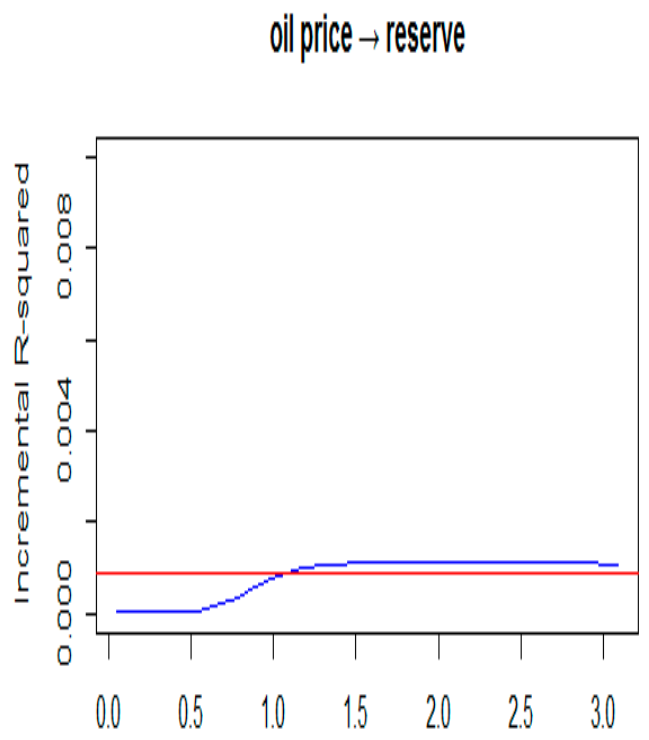

frequency oil price $\rightarrow$ trade balance

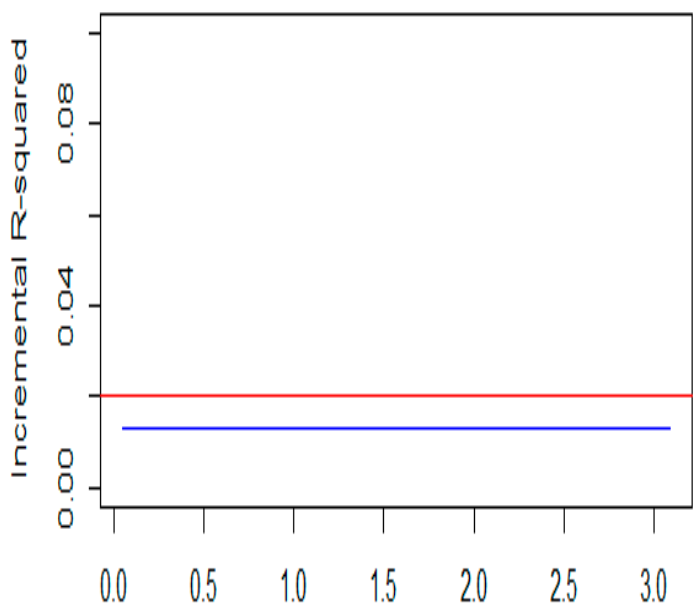

frequency

oil price $\rightarrow$ exchange rate

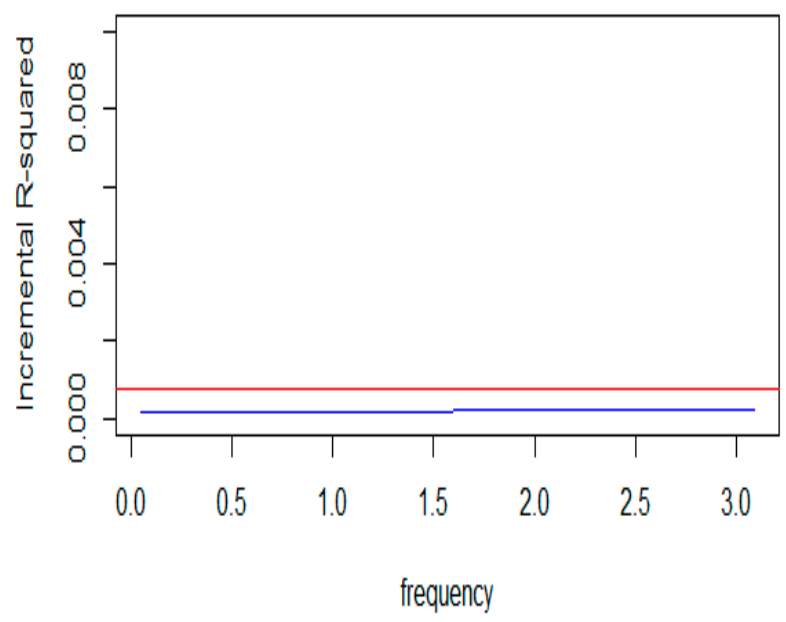

Figure 1. Granger causality of oil price effects on reserve, trade balance, and exchange rate in Nigeria.

\section{Conclusions and Policy Recommendations}

This study examined the causal effects of oil price on exchange rate, trade balance, and reserve in Nigeria between the periods of the fourth quarter of 1986 to the first quarter of 2018. We employed a frequency domain causality test as against the usual time domain causality to capture the possible short-, medium-, and long-term causal effects between the variables of interest. After performing the unit root tests and the cointegration test, we found short term causal effects of oil price on reserve. However, no causal effects were found from oil price to both exchange rate and trade balance.

The absence of causal effects suggests that oil price does not have any significant effect on Nigeria's exchange rate and trade balance. In other words, oil price does not matter for exchange rate and trade balance behavior in Nigeria. The short term causal effects running from oil price to reserve implies that movement in the global oil price plays a major role in reserve keeping in Nigeria in the short period. The findings suggest that short term energy policy would be appropriate for oil price-reserve relationship in Nigeria. The likely implication of the short predictor of oil price on reserve building is that reliance on oil price to build Nigeria's reserve can only be feasible in the short run and not over a 
long period of time. It further implies that Nigeria cannot not rely solely on the foreign exchange from oil price for her reserve building in the long run. The country currently has almost $\$ 42.34$ billion in her reserve and increase in global oil price has been the major source of foreign exchange inflow into the reserve. Diversifying away from oil to other non-oil activities that would generate foreign exchange for reserve building, should be a continuous policy pursuit of the policy makers in the country. In addition, the country can attract other capital inflow apart from oil price for reserve building. Finally, the short run causal effects between oil price and reserve imply that policy makers should have short term and regular policy response to the interactions between the two variables.

Conflicts of Interest: The authors declare no conflict of interest.

\section{Appendix A}

Table A1. VAR lag order selection criteria. Endogenous variables: oil price and trade balance.

\begin{tabular}{ccccccc}
\hline Lag & $\underline{\text { LogL }}$ & $\underline{\text { LR }}$ & $\underline{\text { FPE }}$ & $\underline{\text { AIC }}$ & $\underline{\text { SC }}$ & $\underline{\text { HQ }}$ \\
\hline 0 & -1829.76 & NA & $4.83 \times 10^{10}$ & 30.28 & 30.32 & 30.3 \\
1 & -1539.23 & 566.67 & $4.24 \times 10^{8}$ & 25.54 & 25.68 & 25.6 \\
2 & -1527.29 & 22.89 & $3.72 \times 10^{8}$ & 25.41 & 25.64 & 25.5 \\
3 & -1514.97 & 23.2 & $3.24 \times 10^{8 *}$ & $25.27^{*}$ & $25.59 *$ & $25.4^{*}$ \\
4 & -1513.16 & 3.36 & $3.36 \times 10^{8}$ & 25.31 & 25.72 & 25.48 \\
5 & -1510.4 & 5.02 & $3.43 \times 10^{8}$ & 25.33 & 25.83 & 25.54 \\
6 & -1507.18 & 5.75 & $3.48 \times 10^{8}$ & 25.34 & 25.94 & 25.59 \\
7 & -1505.52 & 2.9 & $3.62 \times 10^{8}$ & 25.38 & 26.07 & 25.66 \\
8 & -1502.87 & 4.55 & $3.71 \times 10^{8}$ & 25.4 & 26.19 & 25.72 \\
\hline
\end{tabular}

LR—likelihood ratio, FPE—final prediction error, AIC—Akaike information criterion, SC—Schwarz information criterion, HQ-Hannan-Quinn information criterion. * signifies optimal lag length.

Table A2. VAR lag order selection criteria. Endogenous variables: oil price and exchange rate.

\begin{tabular}{ccccccc}
\hline Lag & $\underline{\text { LogL }}$ & $\underline{\text { LR }}$ & $\underline{\text { FPE }}$ & $\underline{\text { AIC }}$ & $\underline{\text { SC }}$ & $\underline{\text { HQ }}$ \\
\hline 0 & -797.4 & NA & $1.88 \times 10^{1}$ & 13.21 & 13.26 & 13.23 \\
1 & -600.78 & 383.47 & $7.78 \times 10^{1}$ & 10.02 & $10.17^{*}$ & 10.09 \\
2 & -583.03 & 34.05 & $6.20 \times 10^{1}$ & 9.80 & 10.03 & 9.90 \\
3 & -578.02 & 9.41 & $6.10 \times 10^{1} *$ & $9.79 *$ & 10.11 & $9.92 *$ \\
4 & -576.98 & 1.94 & $6.40 \times 10^{1}$ & 9.83 & 10.25 & 10.00 \\
5 & -573.23 & 6.81 & $6.43 \times 10^{1}$ & 9.84 & 10.35 & 10.04 \\
6 & -570.5 & 4.87 & $6.57 \times 10^{1}$ & 9.86 & 10.46 & 10.10 \\
7 & -569.51 & $1.74 *$ & $6.91 \times 10^{1}$ & 9.91 & 10.6 & 10.19 \\
8 & -566.6 & 4.99 & $7.05 \times 10^{1}$ & 9.93 & 10.71 & 10.25 \\
\hline
\end{tabular}

LR—likelihood ratio, FPE—final prediction error, AIC—Akaike information criterion, SC-Schwarz information criterion, HQ-Hannan-Quinn information criterion. * signifies optimal lag length. 
Table A3. VAR lag order selection criteria. Endogenous variables: Oil price and exchange rate.

\begin{tabular}{ccccccc}
\hline Lag & $\underline{\text { LogL }}$ & $\underline{\text { LR }}$ & $\underline{\text { FPE }}$ & $\underline{\text { AIC }}$ & $\underline{\text { SC }}$ & $\underline{\text { HQ }}$ \\
\hline 0 & -1255.15 & NA & $3.63 \times 10^{3}$ & 20.78 & 20.83 & 20.8 \\
1 & -876.02 & 739.46 & $7.35 \times 10^{3}$ & 14.58 & $14.72 *$ & 14.64 \\
2 & -869.03 & 13.39 & $7.00 \times 10^{3}$ & 14.53 & 14.76 & 14.62 \\
3 & -861.57 & 14.06 & $6.61 \times 10^{3} *$ & $14.47^{*}$ & 14.94 & $14.6^{*}$ \\
4 & -860.89 & 1.26 & $6.99 \times 10^{3}$ & 14.53 & 15.08 & 14.7 \\
5 & -859.52 & 2.47 & $7.30 \times 10^{3}$ & 14.57 & 15.22 & 14.78 \\
6 & -858.64 & 1.59 & $7.69 \times 10^{3}$ & 14.62 & 15.22 & 14.87 \\
7 & -853.06 & $9.78^{*}$ & $7.50 \times 10^{3}$ & 14.6 & 15.29 & 14.88 \\
8 & -851.47 & 2.72 & $7.82 \times 10^{3}$ & 14.64 & 15.42 & 14.95 \\
\hline
\end{tabular}

LR—likelihood ratio, FPE—final prediction error, AIC—Akaike information criterion, SC—Schwarz information criterion, HQ-Hannan-Quinn information criterion. * signifies optimal lag length.

\section{References}

Al-Ezzee, Ibrahim. 2011. Real influences of Real Exchange rate and Oil price changes on the growth of real GDP: Case of Bahrain. Paper presented at International Conference of Management and Service Science IPEDR 8, Wuhan, China, August 12-14.

Aliyu, Shehu Usman Rano. 2009. Impact of Oil Price shock and Exchange Rate Volatility on Economic Growth in Nigeria: An Empirical Investigation. Research Journal of International Studies 11: 4-15.

Asghar, Zahid, and Irum Abid. 2007. Performance of Lag Length Selection Criteria in Three Different Situations. Paper No. 40042. Posted 13 July 2012. Available online: https:/ / mpra.ub.uni-muechen.de/40042/MPRA (accessed on 5 December 2018).

Baak, SaangJoon. 2004. Exchange rate volatility and trade among the Asia pacific. East Asian Economic Review 8: 93-115. Available online: http:/ / repec.org/esFEAM04/up.29293.1080736850.pdf (accessed on 7 December 2018). [CrossRef]

Bayat, Tayfur, Saban Nazlioglu, and Selim Kayhan. 2015. Exchange rate and oil price interactions in transition economics: Czech Republic, Hungary and Poland. Panoeconomicus 62: 267-85. [CrossRef]

Benhabib, Abderrezak, Si Mohammed Kamel, and Samir Maliki. 2014. The Relationship between Oil Price and the Algerian Exchange Rate. Topics in Middle Eastern and African Economies 16: 127-41.

Bouri, Elie, David Roubaud, Rania Jammazi, and Ata Assaf. 2017a. Uncovering frequency domain causality between gold and the stock markets of China and India: Evidence from implied volatility indices. Finance Research Letters. [CrossRef]

Bouri, Elie, Imad Kachacha, Donald Lien, and David Roubaud. 2017b. Short- and long-run causality across the implied volatility of crude oil and agricultural commodities. Economics Bulletin 37: 1077-88.

Breitung, Jörg, and Bertrand Candelon. 2006. Testing for short run and long run causality: A frequency domain approach. Journal of Econometrics 132: 363-78. [CrossRef]

Central Bank of Nigeria Statistical Bulletin. 2018. Annual Publication; Abuja: Central Bank of Nigeria.

Centre for Study of Economies of Africa. 2018. 4 Dep. Street off Danube Street, Maitama, Abuja, FCT, Nigeria. Available online: www.cseaafrica.org (accessed on 25 December 2018).

Chen, Shiu-Sheng, and Hung-Chyn Chen. 2007. Oil prices and real exchange rates. Energy Economics 29: 390-404. [CrossRef]

Coudert, Virginie, Valérie Mignon, and Alexis Penot. 2008. Oil Price and the Dollar. Energy Studies Review 15: 1-20. [CrossRef]

Croux, Christophe, and Peter Reusens. 2013. Do stock prices contain predictive power for the future economic activity? A Granger causality analysis in the frequency domain. Journal of Macroeconomics 35: 93-103. [CrossRef]

Danmola, Rasaq Akonji, and Adijat Olubunkola Olateju. 2013. The Impact of monetary policy on current Account Balance. Journal of Humanities and Social Sciences 7: 67-72.

Dergiades, Theologos, Costas Milas, and Theodore Panagiotidis. 2015. Tweets, Google trends, and sovereign spreads in the GIIPS. Oxford Economic Papers 67: 406-32. [CrossRef] 
Dickey, David A., and Wayne A. Fuller. 1981. Distribution of the estimators for autoregressive time series with a Unit Root. Journal of the American Statistical Association 74: 427-31.

Energy Information Administration, US Federal Statistical System. 2018. Available online: http:/ /www.eia.gov (accessed on 20 December 2018).

Geweke, John. 1982. Measurement of linear dependence and feedback between multiple time series. Journal of American Statistical Association 77: 304-24. [CrossRef]

Gounder, Rukmani, and Matthew Bartleet. 2007. Oil price shocks and economic growth: Evidence for New Zealand, 1989-2006. Paper presented at the New Zealand Association of Economist Annual Conference, Christchurch, New Zealand, June 27-29.

Habib, Maurizio Michael, and Margarita M. Kalamova. 2007. Are There Oil Currencies? The Real Exchange Rate of Oil Exporting Countries. Working Paper Series 839. Frankfurt: European Central Bank.

Hassan, Syeda Anam, and Khalid Zaman. 2012. Effect of oil prices on trade balance: New insights into the cointegration relationship from Pakistan. Economic Modeling 29: 2125-43. [CrossRef]

Huang, Xu, Emmanuel Silva, and Hossein Hassani. 2018. Causality between oil prices and tourist arrivals. Stats 1: 134-54. [CrossRef]

Johansen, Søren. 1988. Statistical analysis of cointegration vectors. Journal of Economic Dynamics and Control 12: 231-54. [CrossRef]

Joseph, Afolabi Ibikunle, and Akhanolu Isaac. 2011. An Empirical investigation of the link between exchange rate volatility and trade in Nigeria. Journal of Emerging Trends in Economics and Management Sciences 2: 175-83.

Ng, Yuen-Ling, Wai-Mun Har, and Geoi-Mei Tan. 2008. Real Exchange rate and trade balance relationship: An Empirical study on Malaysia. International Journal of Business and Management 3: 130-37. Available online: https: / / ssrn.com/abstract=1398329 (accessed on 23 December 2018). [CrossRef]

Nikbakht, Leili. 2010. Oil prices and exchange rate: The case of OPEC. Business Intelligence Journal 3: 88-92.

Ogbonna, BigBen Chukwuma. 2011. The impact of exchange rate variation on trade balance: Evidence from Nigeria, 1970-2005. Journal of Research in National Development 9: 393-403.

Oladipupo, Adesina Oladipupo, and Faith Ogheneovo Onotaniyohuwo. 2011. Impact of exchange rate on balance of payment in Nigeria. African Research Review 5: 73-88. [CrossRef]

Olayungbo, David Oluseun, Olalekan Yinusa, and Anthony Enisan Akinlo. 2011. Effect of Exchange Rate Volatility on Trade in Some Sub-Saharan African Countries. Modern Economy 2: 538. [CrossRef]

Olomola, Philip A., and Akintoye V. Adejumo. 2006. Oil price shock and macroeconomic Activities in Nigeria. International Research Journal of Finance and Economics 3: 28-34.

Ozer, Mustafa, and Melik Kamisli. 2016. Frequency domain causality analysis of interactions between financial markets of Turkey. International Business Research 9: 176-86. [CrossRef]

Ozlale, Ümit, and Didem Pekkurnaz. 2010. Oil price and current account: A structural analysis for the Turkish economy. Energy Policy 38: 4489-96. [CrossRef]

Phillips, Peter Charles Bonest, and Pierre Perron. 1988. Testing for a unit root in time series regressions. Biometrica 75: 335-46. [CrossRef]

Qiangian, Zhang. 2011. The impact of international oil price fluctuation on China's economy. Energy Procedia 5: 1360-64. [CrossRef]

Rautava, Jouko. 2004. The role of oil prices and the real exchange rate in Russia's economy-A Cointegration approach. Journal of Comparative Economics 32: 315-27. [CrossRef]

Rose, Andrew K. 1990. Exchange Rates and Trade Balance. Some evidence from developing countries. Economic Letters 34: 271-75. [CrossRef]

Shafi, Khuram, Liu Hua, and Nazeer Amna. 2013. Exchange rate volatility and oil price shocks. International Journal of Academic Research in Business and Social Sciences 5.

Shehu, Abba Abubakar, and Zhang Youtang. 2012. Exchange rate volatility, trade flows and economic growth in a small open Economy. International Review of Business Research Paper 8: 118-31.

Tiwari, Aviral Kumar, and Phouphet Kyophilavong. 2017. Exchange rate and international reserves in India: A frequency Domain Analysis. South Asia Economic Journal 18: 76-93. [CrossRef]

Tiwari, Aviral Kumar, and Olaolu Richard Olayeni. 2013. Oil price and trade balance: wavelet based analysis for India. Economics Bulletin 33: 2270-86.

Tiwari, Aviral Kumar, Süleyman Bolat, and Özgür Koçbulut. 2015. Revisit budget deficit and inflation: Evidence from time and frequency domain analyses. Theoretical Economic Letters 5: 357-69. [CrossRef] 
Tsen, Wong Hock. 2009. Term-of-trade and trade balance: Some empirical evidence of Asian economies. The International Trade Journal XXIII: 422-57. [CrossRef]

Udoh, Edet Joshua, Sunday Brownson Akpan, Daniel Etim John, and Inimfon Vincent Patrick. 2012. Cointegration between exchange rate volatility and key macroeconomic fundamentals: evidence from Nigeria. Modern Economy 3: 846-55. [CrossRef]

Wu, Po-Chin, Shiao-Yen Liu, and Sheng-Chieh Pan. 2013. Nonlinear bilateral trade balance-fundamentals nexus: A panel regression approach. International Review of Economics and Finance 27: 318-29. [CrossRef]

Yanfeng, Wei. 2013. The dynamic relationships between oil prices and the Japanese economy: A frequency domain analysis. Review of Economic EFinance 3: 57-67.

Yousefi, Ayoub, and Tony S. Wirjanto. 2004. The empirical role of the exchange rate on the crude-oil Price formation. Energy and Economics 26: 783-99. [CrossRef]

Zheng, Yun. 2012. The Impact of Bilateral Exchange Rate on Trade between Thailand and China. Available online: http:/ / eprints.utcc.ac.th/id/eprint/1340 (accessed on 12 December 2018).

(C) 2019 by the author. Licensee MDPI, Basel, Switzerland. This article is an open access article distributed under the terms and conditions of the Creative Commons Attribution (CC BY) license (http:/ / creativecommons.org/licenses/by/4.0/). 